\title{
Bioecological and statistical risk assessment of toxic metals in sediments of a worldwide important wetland: Gala Lake National Park (Turkey)
}

\author{
Cem Tokatli \\ Trakya University, İpsala Vocational School, Department of Laboratory Technology, TURKEY \\ ${ }^{*}$ Corresponding author's e-mail: tokatlicem@gmail.com
}

Keywords: Gala Lake, sediment quality, statistical evaluation, bioecological indices, GIS

\begin{abstract}
Gala Lake National Park that has an international importance is one of the most important wetland ecosystems for Turkey. As same as many aquatic habitats, Gala Lake is under a significant anthropogenic pressure originated from agricultural activities conducted around the lake and from industrial discharges by means of Ergene River.

The aim of this study was to evaluate the sediment quality of Gala Lake and Irrigation Canal by investigating some toxic element accumulations ( $\mathrm{As}, \mathrm{B}, \mathrm{Ni}, \mathrm{Cr}, \mathrm{Pb}, \mathrm{Cd}, \mathrm{Zn}$ and $\mathrm{Cu}$ ) from a statistical perspective. Pearson Correlation Index (PCI) and Factor Analysis (FA) were applied to detected data in order to determine the associated contaminants and effective factors on the system. Potential Ecological Risk Index $\left(\mathrm{R}_{\mathrm{T}}\right)$ and Biological Risk Index based sediment quality guidelines (mERM-Q) applied to detected data in order to assess the ecological and biological risks of heavy metals in the ecosystem. Also Geographic Information System (GIS) technology was used to make visual explanations by presenting distribution maps of investigated elements.

According to the results of PCI, significant positive correlations were recorded among the investigated toxic elements at 0.01 significance level. According to the results of FA, two factors, which were named as "Agricultural Factor" and "Industrial Factor", explained $86.6 \%$ of the total variance. According to the results of Potential Ecological Risk Index, cadmium was found to be the highest risk factor and according to results of Biological Risk Index, nickel and chromium were found to be the highest risk factors for Gala Lake and Irrigation Canal. As a result of the present study, it was also determined that heavy metal contents in sediments of Gala Lake National Park reached to critical levels and the system is intensively under effect of agricultural and industrial originated pollution.
\end{abstract}

\section{Introduction}

Wetlands, which are known as the most biologically diverse of all ecosystems serving as home to a wide range of plant and animal life, play a number of roles in the environment like feeding downstream waters, trapping flood waters, recharging groundwater supplies, removing pollution, providing fish and wildlife habitat, providing water purification, flood control, and shoreline stability (Keddy 2010). Wetlands, which are part of the foundation of water resources of the world and vital to the health of waterways and communities, can also be considered as economic drivers because of their key role in fishing, hunting, agriculture and recreation (www.ramsar.org, water.epa.gov/type/wetlands/).

The Meriç Delta is formed on about 45,000 ha area at the mouth of Meriç River (about 10,000 ha part of the delta lies in Greece lands and remaining area lies in Turkey lands) and it is listed in Class A of International Wetlands, which means that it can house more than 25,000 waterfowls in the same time. Gala Lake, which was declared as "Nature Conservation Area" in 1991 and "National Park" in 2005, is an important part of Meriç Delta (750 ha area) and it allows dwelling many bird species migrating between Europe and Africa. Gala Lake is under an anthropogenic pressure originated from agricultural activities and industrial discharges by means of Ergene River (Kantarc1 1989, Yarar and Magnin 1997, Elipek et al. 2010, Güher et al. 2011). Especially rice agriculture conducted around the Gala Lake is a rather dense and about $25 \%$ of total rice production of Turkey is being supplied from this plain. Gala Lake is being used for irrigation of paddy fields and then irrigation water of paddy fields is being discharged to Gala Lake through mainly Irrigation Canal. Ergene River, which is known as a dramatically contaminated lotic ecosystem, is one of the most important branches of Meriç River and transports this pollution to Gala Lake (Edirne 2005, Tokatlı et al. 2014a, Tokatlı and Baştatlı 2016).

Toxic metals, which have hazardous effects on the ecological balance of environment, are the significant contaminants for the aquatic ecosystems. Significant quantities of toxic metals, which can be strongly accumulated, and biomagnified along water, sediment and aquatic food chain, are being discharged to the aquatic ecosystems in every day (Massoudieh et al. 2010, Yu et al. 2011). It has been well documented and clearly known that sediment may act as a sink of various contaminants and 
pose a significant risk to water quality through complicated biogeochemical exchanges. Consequently, the investigation of sediment quality is an essential and prime component of aquatic ecosystem assessment studies (Jones et al. 2001, Xu et al. 2004, Vosyliene and Jankaite 2006, Farombi et al. 2007).

Many indices have been developed to evaluate the environmental risks of toxic elements in surface sediments and they are widely used to evaluate the sediment quality (Smal et al. 2015, Borowiak et al. 2016). Potential Ecological Risk Index (RI) and Biological Risk Index based sediment quality guidelines (mERM-Q) are two of the most widely used sediment indices used to evaluate the environmental risks (Çiçek et al. 2013). Multivariate statistical techniques have also been used to assess the freshwater ecosystems in especially recent years. Pearson Correlation Index (PCI) that is a measure of the degree of linear dependence between two variables and Factor Analysis (FA) that is being used to determine the effective factors on the environment are quite powerful and most widely used statistical techniques to evaluate the aquatic conditions (Tokatl 12014, Tokatlı et al. 2014b, Köse et al. 2014). Geographic Information System (GIS) that is known to be designed to capture, store, manipulate, analyze, manage, and present all types of spatial, geographical or environmental data provides visual summaries of investigated data to make them easy to evaluate in especially environmental assessment studies (Maliene et al. 2011, Tokatlı et al. 2014a).
The aim of this study was to evaluate the sediment quality of Gala Lake and Irrigation Canal from a bio - ecological and statistical perspective by using some mono (Pearson Correlation Index) and multi (Factor Analysis) statistical techniques and some bio - ecological risk indices (Potential Ecological Risk Index and Biological Risk Index) and present the investigated parameters visually by using GIS based maps. When the location of the study area and the anthropogenic pressure on the system were considered, it can be clearly understood that the investigation of sediment quality and determining toxic element concentrations in sediment of Gala Lake National Park have a vital importance for ecosystem and human health.

\section{Materials and Methods}

\section{Study area and collection of samples}

Gala Lake is located between the Ipsala and Enez Districts of in Edirne City in Turkey, where Meriç River flows to Aegean Sea. It is located between the coordinates of $40^{\circ} 46^{\prime} 11.37^{\prime \prime}$ North and 26¹1'14.87" (DSİ 1986).

The samples were collected in autumn season of 2013 from 20 selected stations ( 11 of them on the lake and 9 of them on the canal). The selected stations on Gala Lake and Irrigation Canal that connects Meriç River to the lake are given in Figure 1-2 and coordinates of the selected stations are given in Table 1. All the lotic and lentic stations on the study area have been selected on

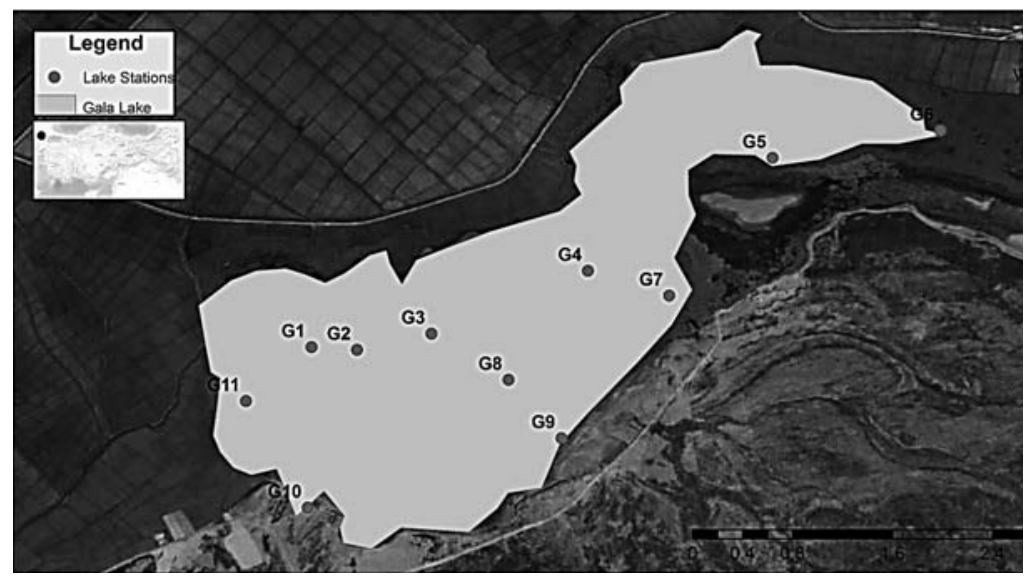

Fig. 1. Gala Lake and the selected stations

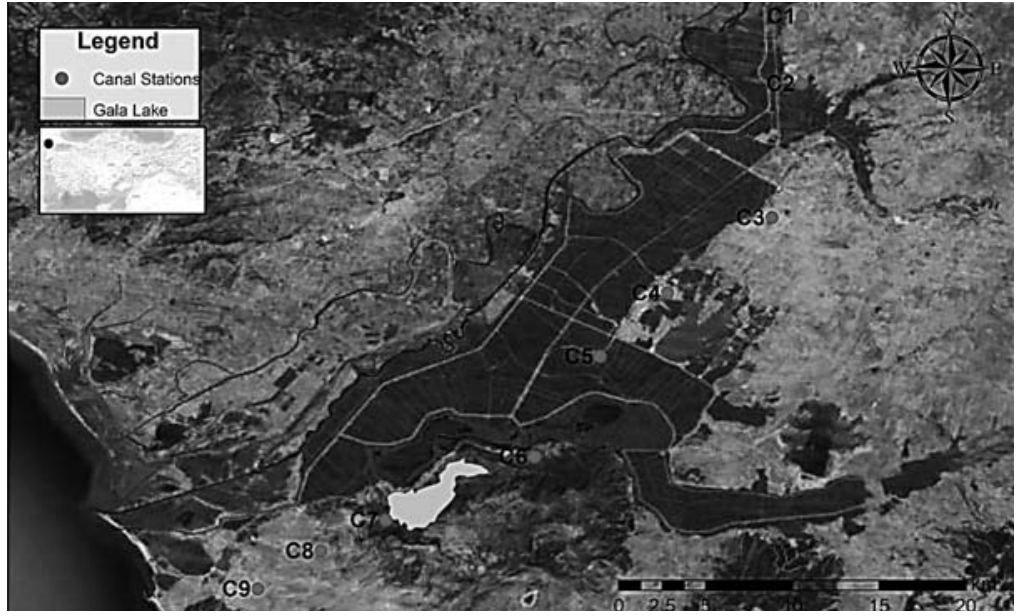

Fig. 2. Irrigation Canal and the selected stations 
Table 1. Coordinates of the selected stations

\begin{tabular}{|c|c|c|c|}
\hline \multirow{2}{*}{ Station } & \multicolumn{2}{|c|}{ Coordinate } & \multirow{2}{*}{ Explanation } \\
\hline & North & East & \\
\hline \multicolumn{4}{|c|}{ Gala Lake (G) } \\
\hline Gala 1 & 40.76779 & 26.16818 & Located on the middle-west sublittoral part of the lake \\
\hline Gala 2 & 40.76759 & 26.17145 & Located on the middle-west sublittoral part of the lake \\
\hline Gala 3 & 40.76875 & 26.17681 & Located on the middle sublittoral part of the lake \\
\hline Gala 4 & 40.77328 & 26.18809 & Located on the middle sublittoral part of the lake \\
\hline Gala 5 & 40.78143 & 26.20137 & Located on the north-east littoral part of the lake \\
\hline Gala 6 & 40.78339 & 26.21345 & Located on the one of input of the canal to the lake \\
\hline Gala 7 & 40.77150 & 26.19394 & Located on the one of input of the canal to the lake* \\
\hline Gala 8 & 40.76543 & 26.18236 & Located on the middle sublittoral part of the lake \\
\hline Gala 9 & 40.76123 & 26.18618 & Located on the middle-south littoral part of the lake \\
\hline Gala 10 & 40.75622 & 26.16791 & Located on the south-west littoral part of the lake \\
\hline Gala 11 & 40.76390 & 26.16346 & Located on the output of the canal \\
\hline \multicolumn{4}{|c|}{ Irrigation Canal (C) } \\
\hline Canal 1 & 41.01972 & 26.37554 & Located on the input of Meriç River to the canal \\
\hline Canal 2 & 40.98471 & 26.37504 & Located on the Sarıcaali Village \\
\hline Canal 3 & 40.91536 & 26.35965 & Located on the İpsala District \\
\hline Canal 4 & 40.87630 & 26.30555 & Located on the Paşaköy Village \\
\hline Canal 5 & 40.84339 & 26.27055 & Located on the Yenikarpuzlu Town \\
\hline Canal 6 & 40.79141 & 26.23650 & Located on the input of the lake \\
\hline Canal 7 & 40.75860 & 26.15937 & Located on the output of the lake \\
\hline Canal 8 & 40.74257 & 26.12577 & Located on the input of the canal to Meriç River \\
\hline Canal 9 & 40.72295 & 26.09304 & Located on the input of Dalyan Lake \\
\hline
\end{tabular}

*: This station was also located on the connection side of the temporary wetland part of Gala Lake

the basis of point and non - point pollution sources, littoral and sublittoral parts of the lake and they are thought to reflect the contamination levels of the investigated wetland ecosystem best.

The sediment samples were collected with an average of three times from each stations both from the canal and the lake by using sediment dipper and Ekman grab taking small portions from the center of the dipper and grab with a polyethylene spoon to avoid contamination by metallic parts of the grab.

\section{Chemical analysis, statistical analysis and GIS maps}

Sediment samples were dried for $3 \mathrm{~h}$ at $105^{\circ} \mathrm{C}$ for element analyses. Then, all sediment samples were placed $(0.25 \mathrm{~g}$ of each sample) in Pyrex reactors of a CEM Mars Xpress 5 microwave digestion unit. $\mathrm{HClO}_{4}: \mathrm{HNO}_{3}$ acids of $1: 3$ proportions were inserted in the reactors respectively. Samples were mineralized at $200^{\circ} \mathrm{C}$ for thirty minutes. Afterwards, the samples were filtered in such a way as to make their volumes to $100 \mathrm{ml}$ with ultra-pure distilled water.

Inductively Coupled Plasma - Optic Emission Spectrophotometric method was used to determine the toxic element accumulations of sediment samples by using a Varian 720 ES ICP - OES Device in an accredited laboratory (Applied Environmental Research Centre Laboratory of Anadolu University). All the investigated toxic element analyses were recorded as averages of triplicate measurements (EPA 1998, EPA 2001). The wavelengths used for toxic element analyses in ICP - OES were given in Table 2.
Table 2. Wavelengths of investigated elements

\begin{tabular}{|l|c|}
\hline Elements & Wavelength $(\mathrm{nm})$ \\
\hline Nickel & 231.604 \\
\hline Zinc & 213.856 \\
\hline Arsenic & 193.759 \\
\hline Boron & 249.678 \\
\hline Cadmium & 226.502 \\
\hline Copper & 324.754 \\
\hline Lead & 220.353 \\
\hline Chromium & 205.552 \\
\hline
\end{tabular}

Pearson Correlation Index (PCI) and Factor Analysis (FA) were applied to the results by using the "SPSS 17" package program. The GIS based distribution maps of parameters were made by using the "ArcGIS" package program.

\section{Sediment quality indices}

\section{Potential ecological risk index $\left(R_{\nu}\right)$}

The potential ecological risk index was developed to evaluate the ecological risks in order to control the aquatic pollution. The methodology is based on the assumption that the sensitivity of the aquatic system depends on its productivity. According to the toxicity of heavy metals and the response of the environment, it was introduced to evaluate the degree of toxic metal pollution in sediments. The potential ecological 
risk index $\left(\mathrm{R}_{\mathrm{r}}\right)$ can be calculated with the following formula (Hakanson 1980);

$$
\begin{gathered}
R_{I}=\sum E_{r}^{i} \\
E_{r}^{i}=T_{r}^{i} C_{f}^{i} \\
C_{f}^{i}=C_{0}^{i} / C_{n}^{i}
\end{gathered}
$$

Where

" $\mathrm{R}_{\mathrm{I}}$ " is calculated as the sum of all risk factors for heavy metals in sediments,

" $\mathrm{E}_{\mathrm{r}}^{\mathrm{i}}$ " is the monomial potential ecological risk factor,

" $\mathrm{T}_{\mathrm{r}}^{\mathrm{i}}$ ", is the toxic response factor for a given substance (Table 3),

" $\mathrm{C}_{\mathrm{f}}^{\mathrm{i}}$ " is the contamination factor, " $\mathrm{C}_{0}^{\mathrm{i}}$ " is the concentration of metals in the sediment and

" $\mathrm{C}_{\mathrm{n}}^{\mathrm{i}}$ " is a reference value for metals (Table 3).

The scale of " $\mathrm{R}_{\mathrm{I}}$ " was given in Table 4 .

\section{Biological risk index ( $m E R M-\mathrm{Q})$}

The sediment quality guidelines (SQGs) were developed from biological toxicity tests of the aquatic benthic environment and classified into three levels by ERL (effect range low) and ERM (effect range medium) as rarely $(<$ ERL), occasionally (ERL - ERM) and frequently (>ERM) associated with adverse biological effects (EPA 2005). A mean ERM quotient (mERM-Q) is developed for evaluating the potential effects of multiple toxic metal contaminations in sediments. The biological risk index (mERM-Q) can be calculated with the following formula (Long et al. 2005);

$$
\begin{gathered}
m E R M-Q=\left(\sum_{f=1}^{n} E R M-Q_{1}\right) / n \\
E R M-Q_{i}=C_{i} / E R M_{i}
\end{gathered}
$$

Where

"mERM-Q" is the effect range median quotient of multiple metal contaminations,

"Ci" is the total content of selected metal,

"ERMi" is the ERM value of selected metal (Table 3) and " $n$ " is the number of selected metals.

The scale of "mERM-Q" was given in Table 4.

\section{Results}

\section{Element accumulations in sediment}

Results of the investigations on toxic metal levels with minimum, maximum and mean values in sediment of Gala Lake and Irrigation Canal are given in Table 5-6 and GIS based distribution maps of toxic metal levels in sediment of Gala Lake are given in Figure 3-4.

\section{Statistical analysis}

The relations between toxic metal levels in sediment of Gala Lake and Irrigation Canal were determined by using Pearson Correlation Index (PCI) and in order to increase the reliability of PCI, all the recorded data from the lake and the canal was used together ( $\mathrm{n}=20$ for all parameters). Results of $\mathrm{PCI}$ and all the detected PCI coefficients are given in Table 7.

\begin{tabular}{|c|c|c|c|c|c|}
\hline \multicolumn{4}{|c|}{ Assessment of potential ecological risk } & \multicolumn{2}{|c|}{ Assessment of biological risk } \\
\hline $\mathrm{E}_{\mathrm{r}}^{\mathrm{i}}$ & $\begin{array}{l}\text { Potential ecological risk } \\
\text { for monomial factor }\end{array}$ & $\mathrm{R}_{\mathrm{l}}$ & $\begin{array}{l}\text { Potential ecological risk } \\
\text { for multinomial factors }\end{array}$ & $\begin{array}{l}\text { ERM-Qi } \\
\text { and } \\
\text { mERM-Q }\end{array}$ & $\begin{array}{l}\text { Biological toxicity risk } \\
\text { for monomial and } \\
\text { multinomial factors }\end{array}$ \\
\hline$<40$ & Low ecological risk & $<95$ & Low ecological risk & $<0.1$ & Low priority side \\
\hline $40-80$ & Moderate ecological risk & $95-190$ & Moderate ecological risk & $0.1-0.5$ & Medium-low priority side \\
\hline $80-160$ & Considerable ecological risk & $190-380$ & Considerable ecological risk & $0.5-1.5$ & High-medium priority side \\
\hline $\begin{array}{c}160-320 \\
>320\end{array}$ & $\begin{array}{l}\text { High ecological risk } \\
\text { Very high ecological risk }\end{array}$ & $>380$ & Very high ecological risk & $>1.5$ & High priority side \\
\hline
\end{tabular}

Table 3. Reference values $\left(C_{n}^{i}\right)$, toxicity coefficients $\left(T_{r}^{i}\right)$, effect range low (ERL) and effect range medium (ERM) values of heavy metals in sediment (Hilton et al. 1985, EPA 2005)

\begin{tabular}{|c|c|c|c|c|}
\hline \multirow{2}{*}{ Elements } & \multicolumn{2}{|c|}{$\mathbf{R}_{\mathbf{I}}$} & \multicolumn{2}{c|}{ mERM-Q } \\
\cline { 2 - 5 } & $\mathrm{C}_{\mathrm{n}}^{\mathrm{i}}$ & $\mathrm{T}_{\mathrm{r}}$ & ERL & ERM \\
\hline $\mathrm{As}$ & 15.00 & 10.00 & 33.00 & 85.00 \\
\hline $\mathrm{Cr}$ & 60.00 & 2.00 & 80.00 & 145.00 \\
\hline $\mathrm{Cu}$ & 30.00 & 5.00 & 70.00 & 390.00 \\
\hline $\mathrm{Pb}$ & 25.00 & 5.00 & 35.00 & 110.00 \\
\hline $\mathrm{Zn}$ & 80.00 & 1.00 & 120.00 & 270.00 \\
\hline
\end{tabular}

Table 4. Scale used to describe the risk factors of $E_{r}^{i}, R_{l}$, ERM-Qi and mERM-Q (Hakanson 1980, Long et al. 2005) 
Table 5. Toxic element concentrations in sediment of Gala Lake (mg/kg)

\begin{tabular}{|c|c|c|c|c|c|c|c|c|c|}
\hline \multirow{2}{*}{\multicolumn{2}{|c|}{ Stations }} & \multicolumn{8}{|c|}{ Elements } \\
\hline & & \multirow{2}{*}{$\frac{\text { Cd }}{0.101}$} & \multirow{2}{*}{$\frac{\mathrm{Cr}}{32.48}$} & \multirow{2}{*}{$\frac{\mathrm{Cu}}{9.820}$} & \multirow{2}{*}{$\begin{array}{c}\mathbf{N i} \\
26.40\end{array}$} & \multirow{2}{*}{$\begin{array}{c}\mathbf{P b} \\
8.460\end{array}$} & \multirow{2}{*}{$\frac{\mathrm{Zn}}{34.90}$} & \multirow{2}{*}{$\frac{\text { B }}{1.827}$} & \multirow{2}{*}{$\begin{array}{c}\text { As } \\
0.039\end{array}$} \\
\hline \multirow{4}{*}{ G1 } & $\min$ & & & & & & & & \\
\hline & $\max$ & 0.240 & 41.06 & 10.06 & 30.64 & 9.940 & 35.32 & 2.796 & 0.054 \\
\hline & mean & 0.187 & 36.74 & 9.933 & 28.96 & 9.326 & 35.05 & 2.207 & 0.044 \\
\hline & STD & 0.075 & 4.290 & 0.120 & 2.252 & 0.771 & 0.231 & 0.516 & 0.008 \\
\hline \multirow{4}{*}{ G2 } & $\min$ & 0.040 & 43.62 & 12.64 & 38.4 & 12.52 & 93.94 & 2.200 & 0.051 \\
\hline & $\max$ & 0.120 & 48.72 & 13.36 & 39.64 & 14.96 & 96.48 & 2.820 & 0.071 \\
\hline & mean & 0.073 & 45.94 & 12.94 & 38.90 & 13.80 & 94.8 & 2.433 & 0.063 \\
\hline & STD & 0.041 & 2.579 & 0.374 & 0.650 & 1.224 & 1.455 & 0.337 & 0.010 \\
\hline \multirow{4}{*}{ G3 } & $\min$ & 0.060 & 55.08 & 10.12 & 31.48 & 8.700 & 36.76 & 2.200 & 0.044 \\
\hline & $\max$ & 0.120 & 60.10 & 10.46 & 32.92 & 9.520 & 37.64 & 3.820 & 0.052 \\
\hline & mean & 0.093 & 57.78 & 10.28 & 32.18 & 9.120 & 37.08 & 2.938 & 0.047 \\
\hline & STD & 0.030 & 2.533 & 0.170 & 0.720 & 0.410 & 0.481 & 0.819 & 0.004 \\
\hline \multirow{4}{*}{ G4 } & $\min$ & 0.120 & 72.62 & 14.08 & 42.38 & 12.92 & 49.26 & 2.000 & 0.109 \\
\hline & $\max$ & 0.300 & 76.44 & 14.40 & 44.08 & 17.96 & 51.12 & 3.440 & 0.223 \\
\hline & mean & 0.213 & 74.22 & 14.28 & 43.10 & 14.98 & 50.10 & 2.560 & 0.161 \\
\hline & STD & 0.090 & 1.980 & 0.179 & 0.879 & 2.642 & 0.941 & 0.771 & 0.057 \\
\hline \multirow{4}{*}{ G5 } & $\min$ & 0.280 & 62.90 & 11.10 & 32.98 & 8.880 & 38.62 & 2.024 & 0.050 \\
\hline & $\max$ & 0.380 & 66.58 & 11.50 & 34.48 & 11.44 & 39.50 & 2.420 & 0.080 \\
\hline & mean & 0.326 & 64.95 & 11.30 & 33.92 & 10.17 & 38.94 & 2.213 & 0.063 \\
\hline & STD & 0.050 & 1.876 & 0.200 & 0.823 & 1.280 & 0.481 & 0.198 & 0.015 \\
\hline \multirow{4}{*}{ G6 } & $\min$ & 0.160 & 105.2 & 21.80 & 49.72 & 9.200 & 65.54 & 16.50 & 0.081 \\
\hline & $\max$ & 0.300 & 120.8 & 23.62 & 51.60 & 12.38 & 66.90 & 25.68 & 0.106 \\
\hline & mean & 0.233 & 111.3 & 22.60 & 50.90 & 10.95 & 66.09 & 20.25 & 0.091 \\
\hline & STD & 0.070 & 8.360 & 0.930 & 1.027 & 1.614 & 0.714 & 4.814 & 0.013 \\
\hline \multirow{4}{*}{ G7 } & $\min$ & 0.560 & 148.9 & 25.80 & 56.46 & 23.38 & 71.18 & 30.00 & 0.265 \\
\hline & $\max$ & 0.640 & 153.2 & 26.40 & 60.04 & 27.94 & 72.76 & 38.54 & 0.292 \\
\hline & mean & 0.613 & 151.1 & 26.15 & 58.19 & 25.14 & 71.91 & 34.33 & 0.283 \\
\hline & STD & 0.046 & 2.130 & 0.313 & 1.792 & 2.447 & 0.796 & 4.271 & 0.015 \\
\hline \multirow{4}{*}{ G8 } & $\min$ & 0.060 & 31.78 & 2.560 & 9.88 & 2.800 & 16.38 & 1.819 & 0.019 \\
\hline & $\max$ & 0.160 & 37.18 & 2.780 & 10.26 & 3.200 & 16.68 & 2.110 & 0.031 \\
\hline & mean & 0.106 & 34.59 & 2.686 & 10.04 & 3.013 & 16.56 & 1.943 & 0.025 \\
\hline & STD & 0.050 & 2.707 & 0.113 & 0.194 & 0.201 & 0.158 & 0.149 & 0.005 \\
\hline \multirow{4}{*}{ G9 } & $\min$ & 0.100 & 50.66 & 9.720 & 28.88 & 8.780 & 77.12 & 3.860 & 0.041 \\
\hline & $\max$ & 0.160 & 67.20 & 9.840 & 30.02 & 12.56 & 78.30 & 5.020 & 0.058 \\
\hline & mean & 0.126 & 59.27 & 9.773 & 29.54 & 10.50 & 77.76 & 4.500 & 0.051 \\
\hline & STD & 0.030 & 8.291 & 0.061 & 0.594 & 1.912 & 0.598 & 0.589 & 0.009 \\
\hline \multirow{4}{*}{ G10 } & $\min$ & 0.680 & 61.94 & 12.08 & 33.18 & 15.26 & 40.00 & 15.05 & 0.054 \\
\hline & $\max$ & 0.920 & 70.58 & 12.36 & 34.74 & 17.80 & 40.70 & 22.58 & 0.081 \\
\hline & mean & 0.813 & 64.95 & 12.18 & 33.95 & 16.73 & 40.42 & 17.89 & 0.071 \\
\hline & STD & 0.122 & 4.876 & 0.151 & 0.780 & 1.316 & 0.370 & 4.084 & 0.015 \\
\hline \multirow{4}{*}{ G11 } & $\min$ & 0.240 & 31.78 & 5.580 & 16.14 & 4.400 & 25.96 & 1.700 & 0.024 \\
\hline & $\max$ & 0.380 & 47.56 & 5.600 & 16.80 & 6.200 & 26.74 & 2.052 & 0.050 \\
\hline & mean & 0.306 & 40.77 & 5.586 & 16.50 & 5.066 & 26.30 & 1.884 & 0.034 \\
\hline & STD & 0.070 & 8.118 & 0.011 & 0.336 & 0.986 & 0.399 & 0.176 & 0.014 \\
\hline
\end{tabular}


Table 6. Toxic element concentrations in sediment of the Irrigation Canal $(\mathrm{mg} / \mathrm{kg})$

\begin{tabular}{|c|c|c|c|c|c|c|c|c|c|}
\hline \multirow{2}{*}{\multicolumn{2}{|c|}{ Stations }} & \multicolumn{8}{|c|}{ Elements } \\
\hline & & \multirow{2}{*}{$\frac{\mathrm{Cd}}{0.240}$} & \multirow{2}{*}{$\frac{\mathrm{Cr}}{94.86}$} & \multirow{2}{*}{$\begin{array}{c}\mathrm{Cu} \\
11.84\end{array}$} & \multirow{2}{*}{$\frac{\mathrm{Ni}}{34.72}$} & \multirow{2}{*}{$\frac{\mathrm{Pb}}{9.640}$} & \multirow{2}{*}{$\frac{\mathrm{Zn}}{38.00}$} & \multirow{2}{*}{$\begin{array}{c}\text { B } \\
7.920\end{array}$} & \multirow{2}{*}{$\begin{array}{c}\text { As } \\
0.051\end{array}$} \\
\hline & $\min$ & & & & & & & & \\
\hline \multirow{3}{*}{ C1 } & $\max$ & 0.340 & 100.3 & 12.64 & 39.12 & 11.84 & 46.38 & 9.600 & 0.063 \\
\hline & mean & 0.293 & 97.92 & 12.11 & 37.04 & 10.61 & 41.86 & 8.953 & 0.059 \\
\hline & STD & 0.050 & 2.791 & 0.455 & 2.209 & 1.121 & 4.233 & 0.904 & 0.006 \\
\hline \multirow{4}{*}{$\mathrm{C} 2$} & $\min$ & 0.22 & 90.86 & 11.60 & 35.12 & 9.440 & 37.20 & 6.720 & 0.021 \\
\hline & $\max$ & 0.26 & 98.72 & 11.62 & 36.72 & 11.64 & 38.82 & 7.600 & 0.024 \\
\hline & mean & 0.24 & 95.96 & 11.60 & 35.70 & 10.41 & 37.93 & 7.173 & 0.023 \\
\hline & STD & 0.02 & 4.427 & 0.011 & 0.881 & 1.121 & 0.820 & 0.440 & 0.001 \\
\hline \multirow{4}{*}{ C3 } & $\min$ & 0.12 & 98.92 & 10.42 & 33.60 & 4.260 & 34.88 & 10.20 & 0.012 \\
\hline & $\max$ & 0.22 & 105.1 & 10.52 & 33.64 & 4.460 & 35.44 & 12.02 & 0.015 \\
\hline & mean & 0.166 & 102.3 & 10.46 & 33.62 & 4.366 & 35.17 & 10.82 & 0.014 \\
\hline & STD & 0.050 & 3.159 & 0.050 & 0.020 & 0.100 & 0.280 & 1.042 & 0.001 \\
\hline \multirow{4}{*}{ C4 } & $\min$ & 0.440 & 73.28 & 11.84 & 39.18 & 4.660 & 42.20 & 14.80 & 0.018 \\
\hline & $\max$ & 0.680 & 109.3 & 12.48 & 40.36 & 7.700 & 43.16 & 15.22 & 0.019 \\
\hline & mean & 0.560 & 89.15 & 12.18 & 39.92 & 6.653 & 42.68 & 15.02 & 0.018 \\
\hline & STD & 0.120 & 18.43 & 0.321 & 0.649 & 1.727 & 0.480 & 0.212 & 0.001 \\
\hline \multirow{4}{*}{ C5 } & $\min$ & 0.380 & 133.8 & 13.38 & 61.94 & 4.240 & 46.64 & 20.18 & 0.041 \\
\hline & $\max$ & 0.600 & 161.8 & 14.20 & 62.60 & 6.200 & 47.72 & 24.00 & 0.045 \\
\hline & mean & 0.506 & 146.1 & 13.80 & 62.17 & 5.146 & 47.01 & 22.58 & 0.043 \\
\hline & STD & 0.113 & 14.35 & 0.410 & 0.370 & 0.988 & 0.612 & 2.094 & 0.002 \\
\hline \multirow{4}{*}{ C6 } & $\min$ & 0.660 & 198.4 & 29.16 & 98.76 & 19.70 & 86.22 & 29.24 & 0.146 \\
\hline & $\max$ & 0.860 & 216.6 & 29.92 & 99.08 & 23.46 & 87.12 & 36.14 & 0.149 \\
\hline & mean & 0.793 & 207.0 & 29.56 & 98.89 & 21.92 & 86.74 & 31.74 & 0.147 \\
\hline & STD & 0.115 & 9.121 & 0.382 & 0.166 & 1.973 & 0.466 & 3.822 & 0.001 \\
\hline \multirow{4}{*}{ C7 } & $\min$ & 0.580 & 178.6 & 37.02 & 84.22 & 32.30 & 107.3 & 7.640 & 0.226 \\
\hline & $\max$ & 0.680 & 214.2 & 37.40 & 86.22 & 35.76 & 111.5 & 10.20 & 0.283 \\
\hline & mean & 0.620 & 199.1 & 37.24 & 85.16 & 33.55 & 109.6 & 9.160 & 0.252 \\
\hline & STD & 0.0529 & 18.37 & 0.200 & 1.005 & 1.916 & 2.107 & 1.345 & 0.028 \\
\hline \multirow{4}{*}{ C8 } & $\min$ & 0.800 & 109.4 & 19.08 & 48.84 & 15.14 & 63.02 & 9.900 & 0.083 \\
\hline & $\max$ & 1.080 & 131.6 & 19.84 & 49.90 & 20.06 & 63.62 & 11.06 & 0.084 \\
\hline & mean & 0.920 & 122.7 & 19.44 & 49.30 & 17.78 & 63.37 & 10.33 & 0.084 \\
\hline & STD & 0.144 & 11.69 & 0.381 & 0.543 & 2.480 & 0.313 & 0.635 & 0.001 \\
\hline \multirow{4}{*}{ C9 } & $\min$ & 0.780 & 42.00 & 19.84 & 14.86 & 18.52 & 60.62 & 4.200 & 0.018 \\
\hline & $\max$ & 0.900 & 56.08 & 19.96 & 15.36 & 23.86 & 60.96 & 6.400 & 0.019 \\
\hline & mean & 0.826 & 51.28 & 19.91 & 15.04 & 20.69 & 60.82 & 5.500 & 0.019 \\
\hline & STD & 0.064 & 8.043 & 0.064 & 0.277 & 2.805 & 0.181 & 1.153 & 0.001 \\
\hline
\end{tabular}

min: minimum; max: maximum; STD: standard deviation

Factor Analyses (FA) were used to determine the effective varifactors on the system by using correlated variables. Uncorrelated variables were removed to increase the reliability of FA and a total of seven variables $(\mathrm{Cu}, \mathrm{Zn}, \mathrm{As}, \mathrm{B}, \mathrm{Cr}$, Ni and $\mathrm{Pb})$ were used to detect the varifactors $(\mathrm{n}=20$ for all parameters). Eigenvalues higher than one were taken as criterion for assess the principal components that required to explain the sources of variance in the data. According to rotated cumulative percentage variance, two factors explained $86.6 \%$ of the total variance (Table 8 ).

The parameter loadings $(>0.5)$ for two components (after rotation) and component plot in rotated space that shows the related variables of two factors are given in Figure 5.

First factor (F1) named as "Agricultural Factor" explained $48.8 \%$ of the total variance, and it was related to the variables 

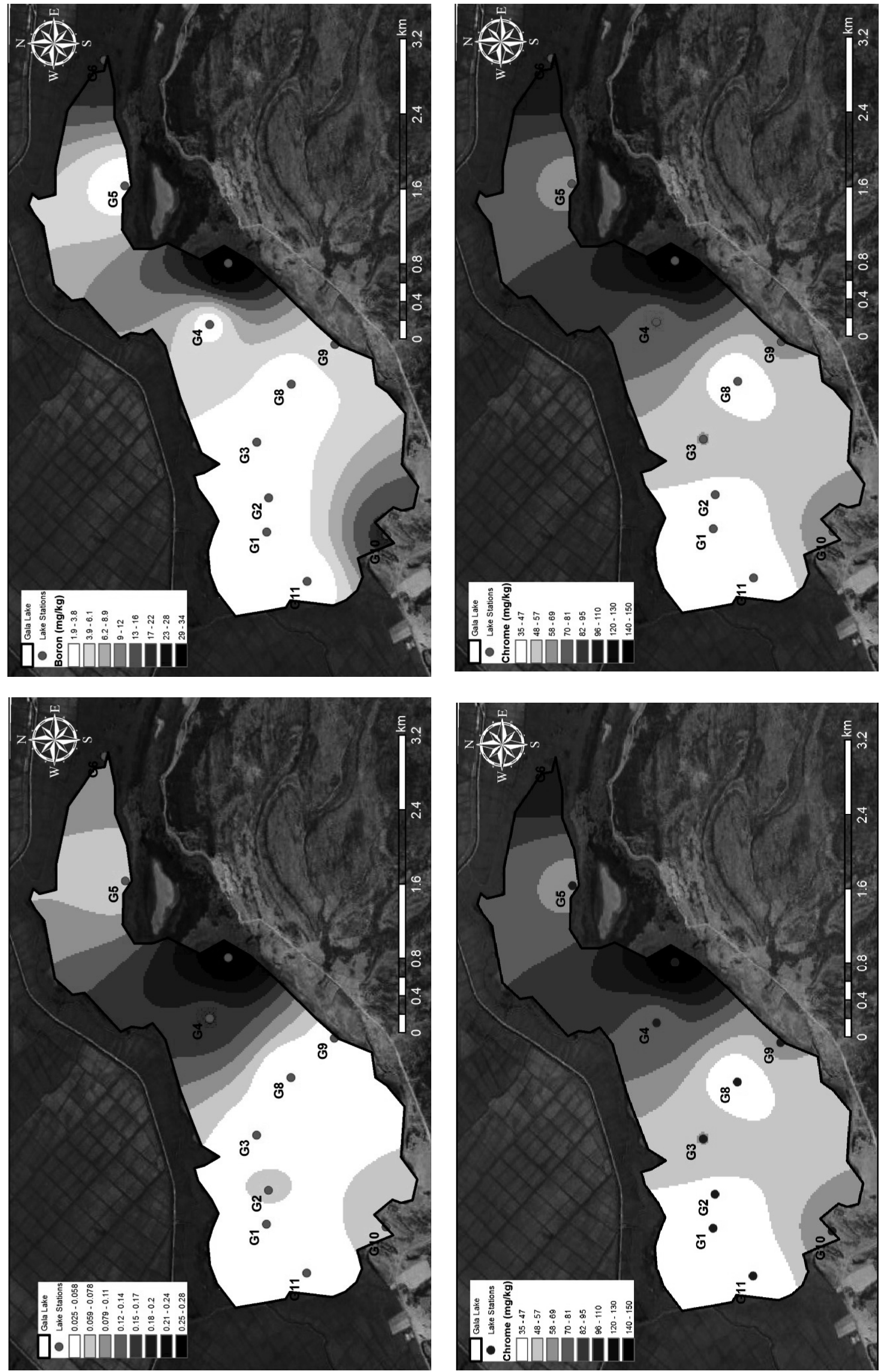

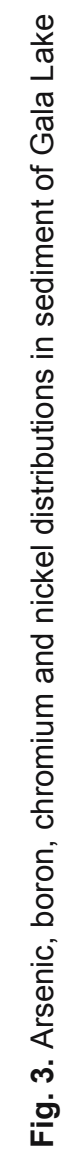



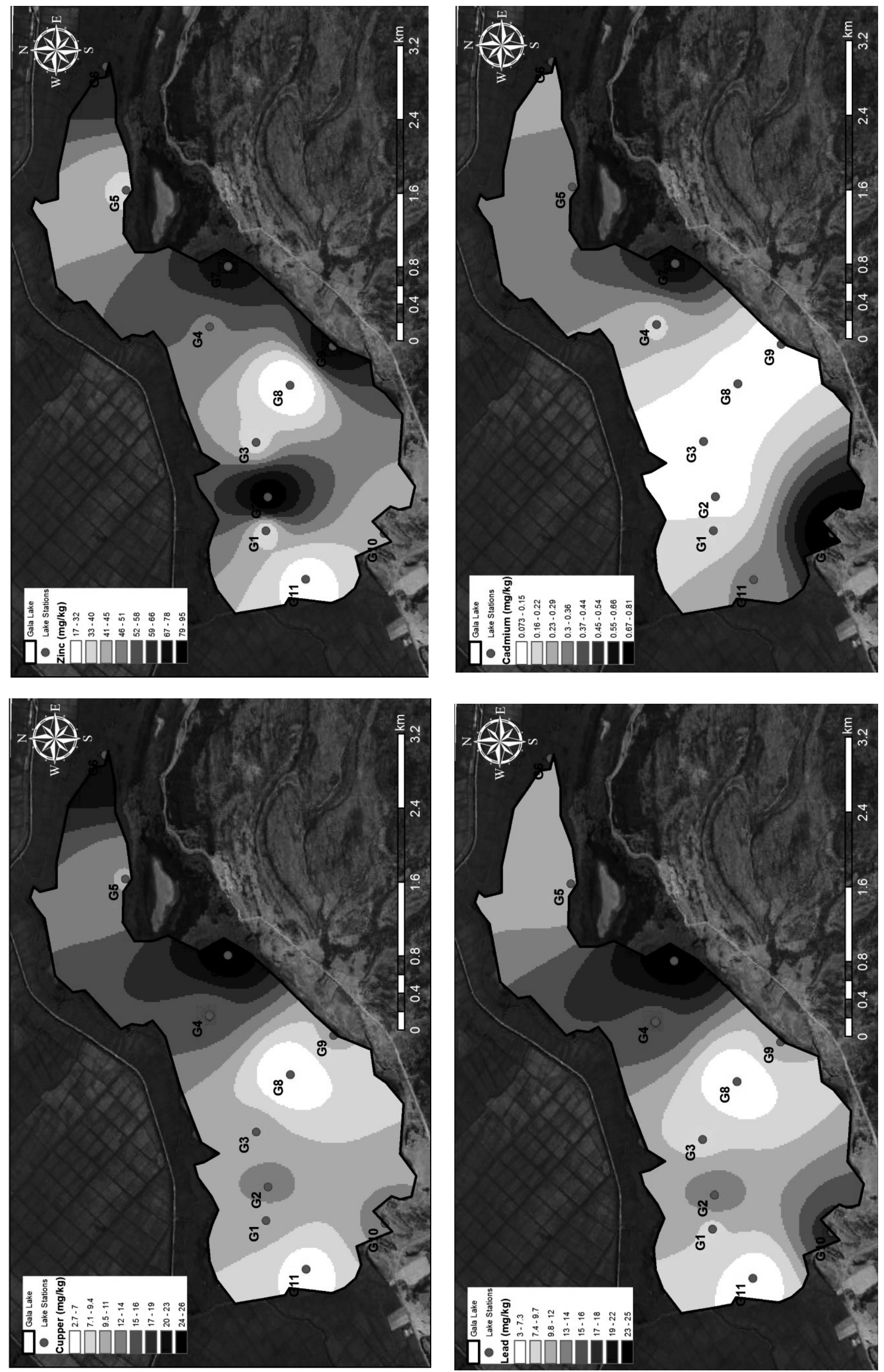
Table 7. Pearson Correlation Index coefficients

\begin{tabular}{|c|cccccccc|}
\hline & $\mathbf{C d}$ & $\mathbf{C r}$ & $\mathbf{C u}$ & $\mathbf{N i}$ & $\mathbf{P b}$ & $\mathbf{Z n}$ & $\mathbf{B}$ & $\mathbf{A s}$ \\
\hline $\mathbf{C d}$ & 1 & & & & & & & \\
$\mathbf{C r}$ & $.519^{*}$ & 1 & & & & & & \\
$\mathbf{C u}$ & $.583^{* *}$ & $.835^{* *}$ & 1 & & & & \\
$\mathbf{N i}$ & .437 & $.937^{* *}$ & $.829^{* *}$ & 1 & & & \\
$\mathbf{P b}$ & $.606^{* *}$ & $.600^{* *}$ & $.886^{* *}$ & $.618^{* *}$ & 1 & & \\
$\mathbf{Z n}$ & .307 & $.585^{* *}$ & $.801^{* *}$ & $.685^{* *}$ & $.774^{* *}$ & 1 & & \\
$\mathbf{B}$ & $.544^{*}$ & $.736^{* *}$ & $.575^{* *}$ & $.679^{* *}$ & .364 & .324 & 1 & \\
$\mathbf{A s}$ & .322 & $.654^{* *}$ & $.779^{* *}$ & $.679^{* *}$ & $.807^{* *}$ & $.628^{* *}$ & $.497^{*}$ & 1 \\
\hline
\end{tabular}

*: Correlation is significant at the 0.05 level $(p<0.05)$;

${ }^{* *}$ : Correlation is significant at the 0.01 level $(p<0.01)$

Table 8. Extracted values of FA parameters

\begin{tabular}{|c|ccc|ccc|ccc|}
\hline \multirow{2}{*}{ Component } & \multicolumn{3}{|c|}{ Initial Eigenvalues } & \multicolumn{3}{c|}{$\begin{array}{c}\text { Extraction Sums of } \\
\text { Squared Loadings }\end{array}$} & \multicolumn{3}{c|}{$\begin{array}{c}\text { Rotation Sums of } \\
\text { Squared Loadings }\end{array}$} \\
\cline { 2 - 10 } & Total & $\begin{array}{c}\text { \% of } \\
\text { Variance }\end{array}$ & $\begin{array}{c}\text { Cumulative } \\
\%\end{array}$ & Total & $\begin{array}{c}\% \text { of } \\
\text { Variance }\end{array}$ & $\begin{array}{c}\text { Cumulative } \\
\%\end{array}$ & Total & $\begin{array}{c}\text { \% of } \\
\text { Variance }\end{array}$ & $\begin{array}{c}\text { Cumulative } \\
\%\end{array}$ \\
\hline $\mathbf{1}$ & 5.122 & 73.174 & 73.174 & 5.122 & 73.174 & 73.174 & 3.419 & 48.845 & 48.845 \\
$\mathbf{2}$ & 0.946 & 13.518 & 86.692 & 0.946 & 13.518 & 86.692 & 2.649 & 37.847 & 86.692 \\
\hline
\end{tabular}

agricultural Factor Industrial Factor

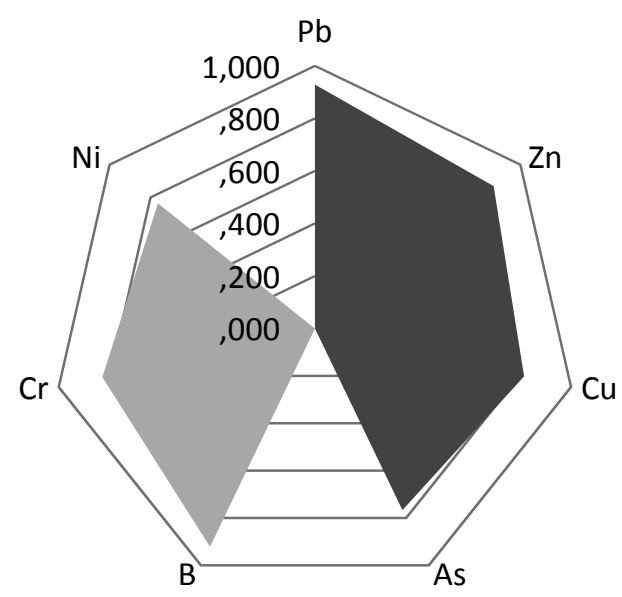

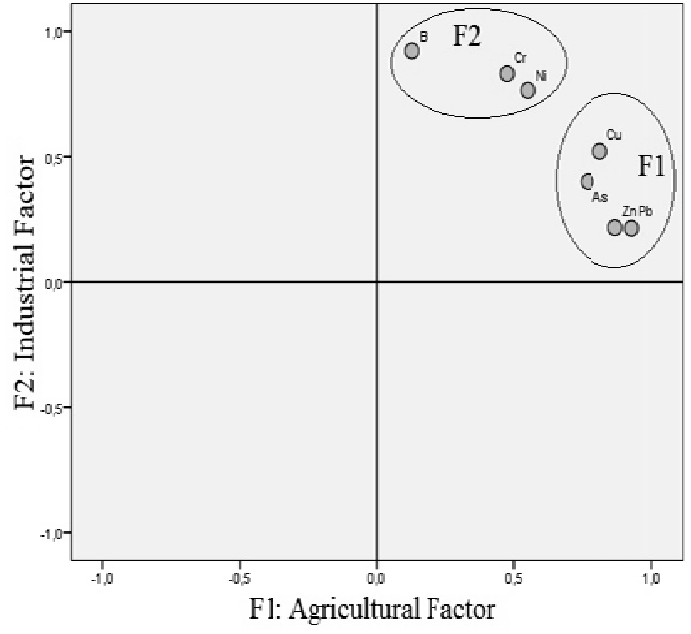

Fig. 5. Component matrix (left side) and component plot (right side) of $\mathrm{Pb}, \mathrm{Zn}, \mathrm{Cu}$ and As parameters. All parameters were "strong positively" loaded with this factor.

Second factor (F2) named as "Industrial Factor" explained $37.8 \%$ of the total variance, and it was related to the variables of $\mathrm{Ni}, \mathrm{Cr}$ and $\mathrm{B}$ parameters. All parameters were "strong positively" loaded with this factor.

\section{Bioecological risk indices}

The potential ecological risk indices monomial $\left(\mathrm{E}_{\mathrm{r}}^{\mathrm{i}}\right)$ and multinomial $\left(\mathrm{R}_{\mathrm{I}}\right)$ and biological risk indices monomial (ERM-Qi) and multinomial (mERM-Q) for each station selected on the Gala Lake and Irrigation Canal were identified and all the results are given in Table 9.

$\mathrm{E}_{\mathrm{r}}^{\mathrm{i}}$ is the monomial and $\mathrm{R}_{\mathrm{I}}$ is the multinomial heavy metal potential ecological risk indices; ERM-Qi is the monomial and $\mathrm{mERM}-\mathrm{Q}$ is the multinomial biological risk indices;
Bold types indicate the sample sites with moderate ecological risks for "potential ecological risk index" and high-medium and high priority sides for "biological risk index"

According to the results of monomial potential ecological risk indices $\left(\mathrm{E}_{\mathrm{r}}^{\mathrm{i}}\right)$, cadmium posed moderate ecological risk at G10 station on the Gala Lake and at C6, C8 and C9 stations on the Irrigation Canal. The potential ecological risk indices for monomial regulators indicted that the intensity of the investigated toxic metals can be followed as $\mathrm{Cd}>\mathrm{Ni}>\mathrm{Cr}>\mathrm{Pb}$ $>\mathrm{Cu}>\mathrm{Zn}>$ As.

According to the results of multinomial potential ecological risk indices $\left(\mathrm{R}_{\mathrm{I}}\right)$, all the investigated stations exhibited low ecological risk. The potential ecological risk indices for multinomial regulators indicted that the ecological risks of the system can be sorted as Irrigation Canal $>$ Gala Lake (Figure 6). 


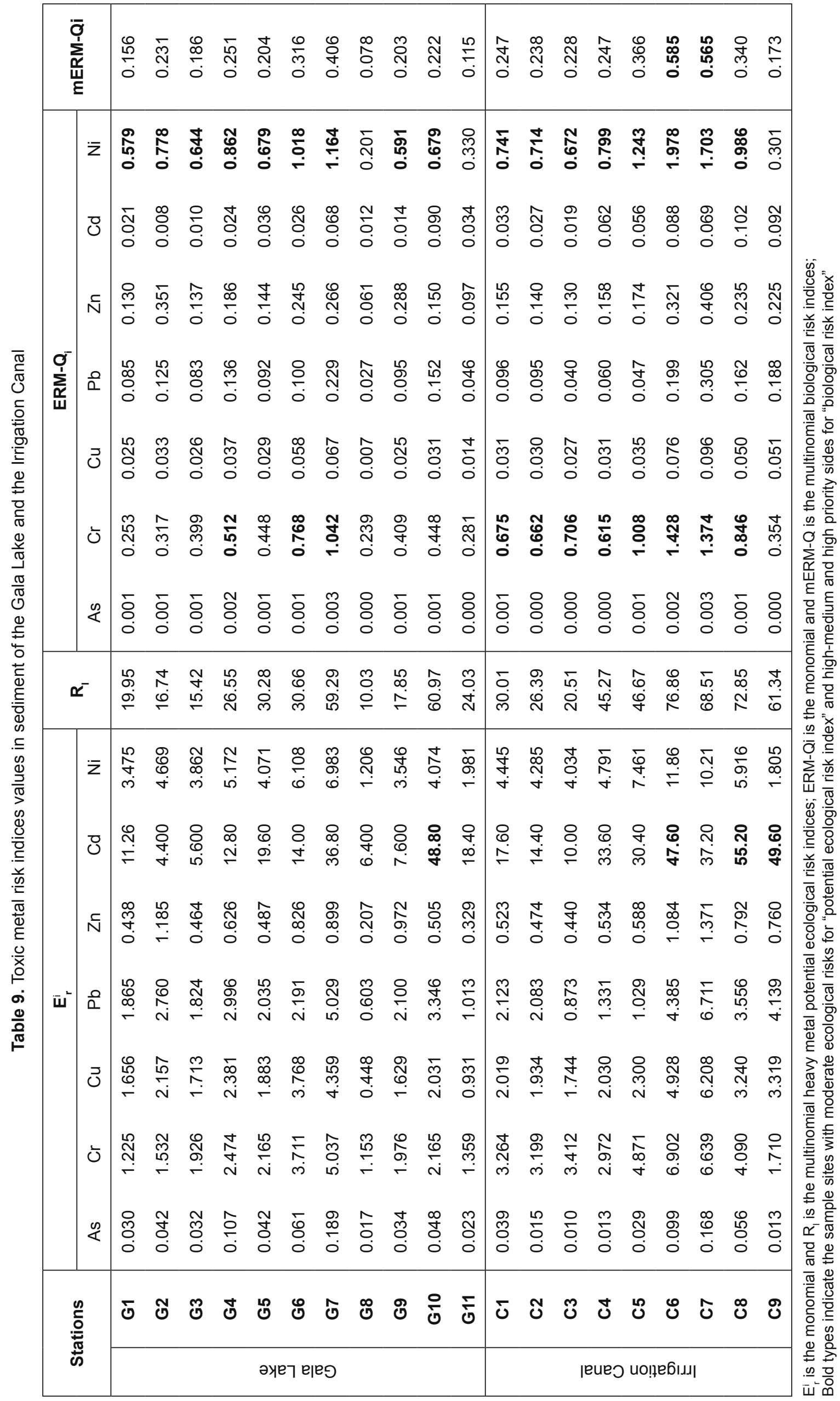


According to the results of monomial biological risk indices (ERM-Qi), zinc posed medium - low priority side at almost all stations on the system. Lead posed medium - low priority side at G2, G4, G6, G7 and G10 stations on the Gala Lake and at C6, C7, C8 and C9 stations on the Irrigation Canal. Chromium posed high - medium priority side at G4, G6 and G7 stations on the Gala Lake and at almost all stations on the Irrigation Canal. Nickel posed high - medium priority side at almost all stations on the system and posed high priority side at $\mathrm{C} 6$ and $\mathrm{C} 7$ on the Irrigation Canal. The biological risk indices for monomial regulators indicted that the intensity of the investigated toxic metals can be followed as $\mathrm{Ni}>\mathrm{Cr}>\mathrm{Zn}$ $>\mathrm{Pb}>\mathrm{Cd}>\mathrm{Cu}>$ As.

According to the results of multinomial biological risk indices (mERM-Q), all the investigated stations on the system except G8 station on Gala Lake and C6 and C7 stations on the Irrigation Canal exhibited medium - low priority side. G8 station on Gala Lake exhibited low priority side and C6 and C7 stations on Irrigation Canal exhibited high - medium priority side. The biological risk indices for multinomial regulators indicted that the biological risks of the system can be sorted as Irrigation Canal $>$ Gala Lake (Figure 7).

\section{Discussion}

Use of pesticides in agricultural applications contains significant quantities of lead and arsenic and it is known that hunting activities, which is intensively being conducted on Gala Lake because of significant presence of birds, have a significant effect on the lead contamination in the environment (one shot contains 32 gr lead) (ATSDR 2005a, ATSDR 2007, Çiçek et al. 2013). Also fertilizers being used in especially paddy fields have a significant impact on zinc and copper transition to the soil and sediment (ATSDR 2004, ATSDR 2005b). Cadmium that is another agricultural origin toxic metal can easily emitted to soil and water by application of phosphate fertilizers, which are known to be intensively used in the region, and also can accumulate in aquatic organisms and agricultural

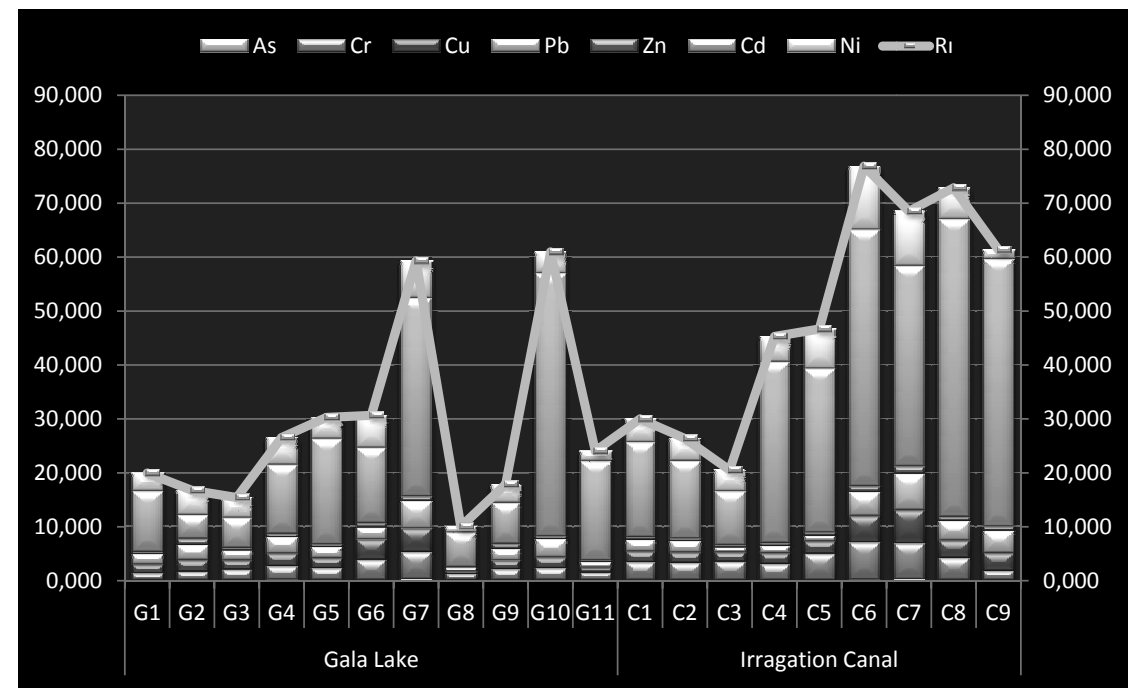

Fig. 6. Values of Potential Ecological Risk Index

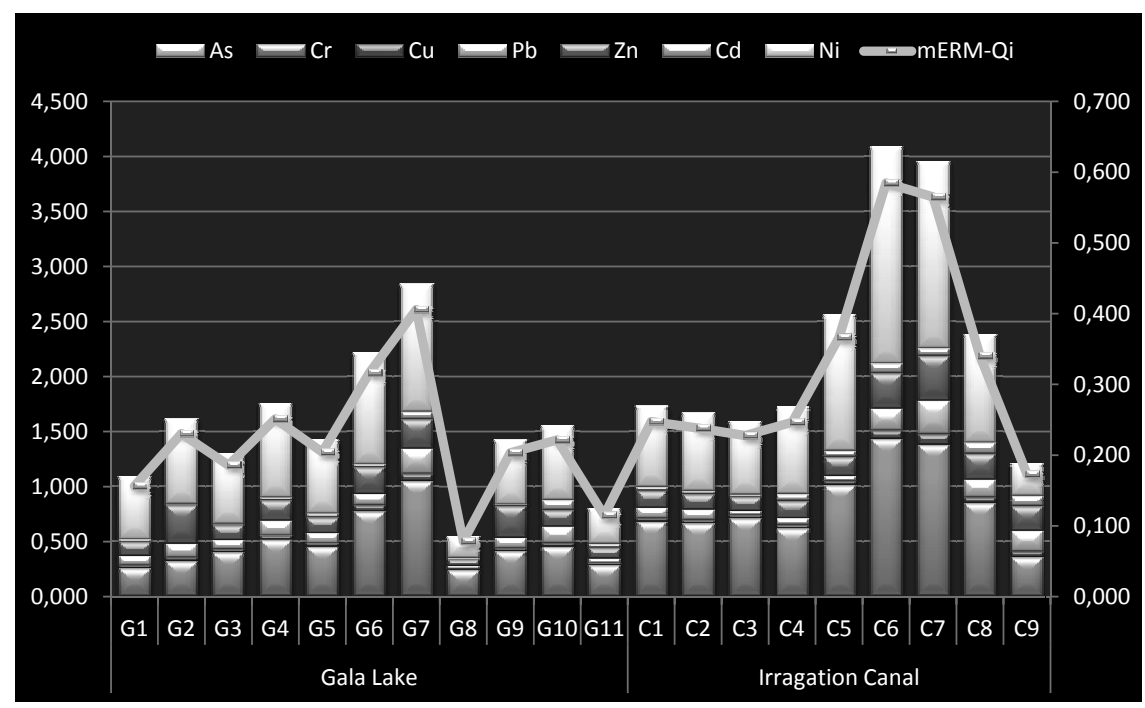

Fig. 7. Values of Biological Risk Index 
crops (ATSDR 2008). In the present study, arsenic, lead, zinc and copper elements were found to be as the significant components of "Agricultural Factor" with strong parameter loadings. Also according to the results of Potential Ecological Risk Index, cadmium that binds strongly to organic matter and be taken up by plant life and can be included to the food chain was found to be the most risky element in the region. Köleli and Kantar (2005) investigated the cadmium contents of different fertilizer samples taken from different fertilizer factories in Turkey and they reported that the cadmium contents of many fertilizers used in Turkey were found to be over the limit values notified for fertilizers. Phosphate rock that is the main ingredient of phosphate fertilizers is being imported to Turkey. Cadmium content of these raw material compounds both imported and produced in Turkey are much more than it should be. As a result of using these phosphate fertilizers in agricultural applications unconsciously, especially phosphate rock compounds accumulated on the land surface are being moved to streams, rivers and lakes (Emiroğlu et al. 2013). There are lots of agricultural lands around the Gala Lake National Park and the results of the present study indicate that this globally important wetland ecosystem is intensively under effect of agricultural activities conducted unconsciously around the lake.

Nickel is a hard, silvery - white metal and has properties that make it very desirable for combining with other metals and one of the significant metals that nickel can be alloyed with is chromium. They occur naturally in the Earth's crust and they may enter to the environment a result of natural processes and mostly by human activities. The most significant anthropogenic point sources of chromium and nickel in surface waters and sediments are the wastewater from electroplating operations, leather tanning industries and textile manufacturing, which are all located on Ergene River Basin (ATSDR 2000, ATSDR 2005c). In the present study, chromium and nickel elements were found to be as the significant components of "Industrial Factor" with strong parameter loadings. Also according to the results of Biological Risk Index, chromium and nickel that can attach strongly to the soil and sediment were found to be the most risky elements in the region. In a study performed in a significant chromium mine basin in Turkey, Tokatli et al (2014) reported that chromium and nickel concentrations in biotic and abiotic components of Emet Stream Basin were found to be at extremely high levels and exceed the national and international limit values. In the present study, some recorded chromium and nickel data detected in sediment of Gala Lake on especially input stations of the canal to the lake (G6 and G7 stations) were significantly higher than the recorded values in sediment of Emet Stream Basin. These results indicate that although the system has an indirect connection with Ergene River through Meriç River, Gala Lake National Park is dramatically being affected by the industrial contamination.

In order to provide visual explanations of investigated toxic metal distributions on Gala Lake, Geographic Information System (GIS) technology was applied to detected data. According to the results of toxic element distribution maps, mainly chromium and nickel contents that are known to have an industrial origin, almost all the investigated toxic metal accumulation levels in sediment samples of Gala Lake were significantly found to be at very high levels on the input stations of the canal to the lake (G6 and G7 stations), which are the connection ways of Ergene River to the system through Meriç River by means of Irrigation Canal. It was also determined that almost all the investigated toxic metal accumulations were significantly found to be at low levels on the output station of the lake to the canal (G11 station). Therefore it can be concluded that Irrigation Canal has left a large part of toxic metal contents to Gala Lake. In a study performed in Kütahya Province of Turkey, toxic metal accumulations in Felent Stream Basin were investigated. According to detected data, Enne Lake that is located on the Felent Stream Basin was found to be a significant barrier for the downstream of the system in terms of toxic metal contamination levels (Tokatl et al. 2013). In another study performed in Porsuk Stream Basin, it was determined that Porsuk Lake, which is located on the basin, has an important cleaning capacity in terms of toxic element accumulations and sediment quality of Porsuk Stream is getting better significantly after the output of Porsuk Lake (Köse et al. 2015). Similar to these studies, Gala Lake was found to be a barrier for the downside of the system in terms of almost all the investigated toxic metals and it has a significant cleaning capacity from the entrance to exit points of the canal in the lake.

Significant correlations between specific toxic metals may reflect similar levels of contamination in the sediments or release from the same sources of pollution (Håkanson and Jansson 1983, Li et al. 2009). In the present study, significant relations were recorded among almost all the investigated parameters. It was also known that according to loading values in Factor Analysis, Liu et al. (2003) classified the factor loadings as "strong $(>0.75)$ ", "moderate $(0.75-0.50)$ " and "weak (0.50-0.30)". In the present study, two factors explained the vast majority of the total variance $(86.6 \%)$ with only strong positively loadings with these two factors. These statistical results may reflect that the contamination sources of this aquatic ecosystem do not pose significant diversity and in a macroscopic point of view, Ergene River may be considered as the "major point pollution source" of the system and the agricultural applications may be considered as "major non - point pollution source" of the system.

\section{Conclusions}

In the present study, some statistical techniques, bio - ecological risk indices and GIS technology were used to evaluate the sediment quality of a significant aquatic ecosystem in Thrace Region of Turkey. According to the results of Factor Analysis, two statistically effective factors named as "Agricultural Factor" and "Industrial Factor" on sediment quality of the system were identified by using a large number of inorganic sediment quality data. According to the results of Potential Ecological Risk Index, cadmium was found to be the highest risk factor for the system. And it posed a "moderate risk" at $9.09 \%$ of the Gala Lake and $33.3 \%$ of the Irrigation Canal. According to results of Biological Risk Index, nickel and chromium were found to be the highest risk factors for the system. And chromium posed a "high - medium priority" at $27.2 \%$ of the Gala Lake and $88.8 \%$ of the Irrigation Canal; nickel posed a "high - medium priority" at $81.8 \%$ of the Gala Lake and $66.6 \%$ of the Irrigation Canal and it posed a "high priority" at $22.2 \%$ of the Irrigation Canal. According to the results of GIS distribution maps, almost all the investigated 
toxic metal accumulations, mainly the industry originated ones were detected at significantly higher levels on the input stations of Irrigation Canal to Gala Lake than detected on the output station of the lake to the canal.

The data of the present study clearly reveals that agricultural runoff caused from intensive pesticide and fertilizer applications and industrial runoff caused from Ergene River were the main pollution sources for the system. Also the present study clearly presents the necessity and availability of the statistical techniques, bio-ecological risk indices and GIS technology on freshwater sediment quality assessment studies.

In accordance with the obtained data of the present study, in order to protect the sustainability of this globally important wetland;

- Monoculture practices in agricultural activities conducted around the region should be changed, and the farmers should be informed about the environment. Also the local people should be encouraged to polyculture practices by applying some legal sanctions if necessary,

- Use of unconscious chemical fertilizers and pesticides in agricultural activities should be avoided by giving the necessary training and environmental awareness for local people,

- Discharges of the industrial wastewater without any treatment to the system from the industrial areas located especially on Ergene River Basin must be prevented,

- Discharges of the municipal sewage without any treatment to the system from the settlement areas must be prevented, and rainwater - sewage water outlets should be designed separately and not to exceed the volume of the septic treatment plant even in a heavy rainfall,

- Water quality of the wetland should be monitored in a short - term period in order to determine the instantaneous discharges, and sediment quality of the wetland and the toxic metal bioaccumulations in biotic components of the wetland should be monitored in a long -term period in order to determine the long - term effects on the system.

\section{Acknowledgement}

The author would like to thank for the financial and technical supports supplied by Trakya University, Turkey. This investigation has been supported by the project numbered as 2013/73 accepted by Trakya University, Commission of Scientific Research Projects.

\section{References}

ATSDR (Agency for Toxic Substances and Disease Registry) (2000). Toxicological Profile for Chromium. Atlanta, GA: U.S. Department of Health and Human Services.

ATSDR (Agency for Toxic Substances and Disease Registry) (2004). Toxicological Profile for Copper. Atlanta, GA: U.S. Department of Health and Human Services.

ATSDR (Agency for Toxic Substances and Disease Registry) (2005a). Toxicological Profile for Arsenic. Atlanta, GA: U.S. Department of Health and Human Services.

ATSDR (Agency for Toxic Substances and Disease Registry) (2005b). Toxicological profile for Zinc. U.S. Department of Health and Human Services.
ATSDR (Agency for Toxic Substances and Disease Registry) (2005c). Toxicological Profile for Nickel. Atlanta, GA: U.S. Department of Health and Human Services.

ATSDR (Agency for Toxic Substances and Disease Registry) (2007). Toxicological Profile for Cadmium. Atlanta, GA: U.S. Department of Health and Human Services.

ATSDR (Agency for Toxic Substances and Disease Registry) (2008). Toxicological Profile for Chromium. Atlanta, GA: U.S. Department of Health and Human Services.

Borowiak, K., Kanclerz, J., Mleczek, M., Lisiak, M. \& Drzewiecka, K. (2016). Accumulation of $\mathrm{Cd}$ and $\mathrm{Pb}$ in water, sediment and two littoral plants (Phragmites australis, Typha angustifolia) of freshwater ecosystem, Archives of Environmental Protection, 42, 3, pp. 47-57.

Çiçek, A., Tokatlı, C. \& Köse, E. (2013). Ecological risk assessment of heavy metals in sediment of felent stream (Sakarya River Basin, Turkey), Pakistan Journal of Zoology, 45 (5): pp. 1335-1341.

DSİ (1986). Gala Lake Limnological Research Report, T.C. Ministry of Energy and Natural Resources, Ankara, 126. (in Turkish)

Edirne (2005). Edirne Provincial Environmental Status Report. Provincial Environment and Forestry Directorate of Edirne Governorship. (in Turkish)

Elipek, B. Ç., Arslan, N., Kirgiz,T., Öterler B., Güher, H. \& Özkan, N. (2010). Analysis of benthic macroinvertebrates in relation to environmental variables of Lake Gala, a National Park of Turkey, Turkish Journal of Fisheries and Aquatic Sciences, 10, pp. 235-243.

Environmental Protection Agency (EPA) METHOD 3051. (1998). Microwave assisted acid digestion of sediments, sludges, soils, and oils.

Environmental Protection Agency (EPA) METHOD 200.7. (2001). Determination of metals and trace elements in water and wastes by inductively coupled plasma-atomic emission spectrometry.

Environmental Protection Agency (EPA) (2005). Predicting toxicity to amphipods from sediment chemistry. EPA/600/R-04/030, Washington, DC.

Emiroğlu, Ö., Uyanoğlu, M., Başkurt, S., Sülün, Ş., Köse, E., Tokatl1, C., Uysal, K., Arslan, N. \& Çiçek, A. (2013). Erythrocyte deformations in Rutilus rutilus (Linnaeus, 1758) provided from porsuk dam (Turkey), Biological Diversity and Conservation, 6(1), pp. 13-17.

Farombi, E.O., Adelowo, O.A. \& Ajimoko. Y.R. (2007). Biomarkers of oxidative stress and heavy metal levels as indicators of environmental pollution in African Cat fish (Clarias gariepinus) from Nigeria ogun river, International Journal of Environmental Research and Public Health, 4(2), pp. 158-165.

Güher, H., Erdoğan, S., Kırgız, T. \& Elipek, B.Ç. (2011). The dynamics of zooplankton in national park of Lake Gala (Edirne-Turkey), Acta Zoologica Bulgarica, 63(2), pp. 157-168.

Håkanson, L. (1980). An ecological risk index for aquatic pollution control of sediment ecological approach, Water Research, 14, $975 \mathrm{e} 1000$.

Håkanson, L. \& Jansson, M. (1983). Principles of lake sedimentology, Springer Verlag, Berlin 1983.

Hilton, J., Davison, W. \& Ochsenbein, U. (1985). A mathematical model for analysis of sediment coke data, Chemical Geology, 48, $281 \mathrm{e} 291$.

http://www.ramsar.org/(17.11.2016)

http://water.epa.gov/type/wetlands/(17.11.2016)

Jones, I., Kille, P. \& Sweeney, G. (2001). Cadmium delays growth hormone expression during rainbow trout development, Journey of Fish Biology, 59, pp. 1015-1022.

Kantarc1, M.D. (1989). The possibilities of assessing the ecological characteristics of the Hisarl Mount and the Gala Lake and its environs as a protected area of nature. Gala Lake and its problems symposium, Association for the Conservation of Nature, Series of Scientific Publications, pp. 12-24. (in Turkish) 
Keddy, P.A. (2010). Wetland ecology principles and conservation, Cambridge University Press, ISBN 978-0-521-51940-3.

Köleli, N. \& Kantar, Ç. (2005). Concentration of toxic heavy metal $(\mathrm{Cd}, \mathrm{Pb}, \mathrm{Ni}, \mathrm{As})$ in phosphate rock, phosphoric acid and phosphorous fertilizers, Ecology, 14, 55, pp. 1-5. (in Turkish)

Köse, E., Tokatlı, C. \& Çiçek, A. (2014). Monitoring stream water quality: a statistical evaluation, Polish Journal of Environmental Studies, 23(5), pp. 1637-1647.

Köse, E., Çiçek, A., Uysal, K., Tokatlı, C., Emiroğlu, Ö. \& Arslan, N. (2015). Heavy metal accumulations in water, sediment and some cyprinidae fish species from Porsuk Stream (Turkey), Water Environment Research, 87(3), pp. 195-204.

Li, F.Y., Fan, Z.P., Xiao, P.F., Oh, K., Ma, X.P. \& Hou, W. (2009). Contamination, chemical speciation and vertical distribution of heavy metals in soils of an old and large industrial zone in Northeast China, Environmental Geology, 54, 1815e1823.

Liu, C.W., Lin, K.H. \& Kuo, Y.M. (2003). Application of factor analysis in the assessment of groundwater quality in a Blackfoot disease area in Taiwan, Science of the Total Environment, 313, pp. 77-89.

Long, E.R., Ingersoll, C.G. \& MacDonald, D.D. (2005). Calculation and uses of mean sediment quality guideline quotients: a critical review, Environmental Science \& Technology, 40, pp. 1726-1736.

Maliene, V., Grigonis, V., Palevičius, V. \& Griffiths, S. (2011). Geographic information system: Old principles with new capabilities, Urban Design International, 16(1), pp. 1-6.

Massoudieh, A., Bombardelli, F.A. \& Ginn, T.R. (2010). A biogeochemical model of contaminant fate and transport in river waters and sediments, Journal of Contaminant Hydrology, 112, pp. 103-117.

Smal, H., Ligęza, S., Wójcikowska-Kapusta, A., Baran, S., Urban, D., Obroślak, R. \& Pawłowski, A. (2015). Spatial distribution and risk assessment of heavy metals in bottom sediments of two small dam reservoirs (south-east Poland), Archives of Environmental Protection, 41, 4, pp. 67-80.

Tokatl1, C. (2014). Drinking water quality of a rice land in Turkey by a statistical and GIS Perspective: Ipsala District, Polish Journal of Environmental Studies, 23 (6), pp. 2247-2258.

Tokatl1, C. \& Baştatlı, Y. (2016). Trace and toxic element levels in river sediments, Polish Journal of Environmental Studies, 25, (4), pp. 1715-1720.

Tokatlı, C., Çiçek, A., Köse, E. \& Emiroğlu, Ö. (2013). Uptake of silver from large silver deposits on biotic and abiotic components of the closest lothic system: Felent Stream, Turkey, Pakistan Journal of Zoology, 4, (3), pp. 701-707.

Tokatli, C., Köse, E., Uğurluoglu, A., Cicek, A. \& Emiroglu, Ö. (2014a). Evaluation of water quality of Gala Lake (Edirne) using Geographic Information System (GIS), Sigma Journal of Engineering and Natural Sciences, 32, pp. 490-501. (in Turkish)

Tokatlı, C., Çiçek, A., Emiroğlu, Ö., Arslan, N., Köse, E. \& Dayığlu, H. (2014b). Statistical approaches to evaluate the aquatic ecosystem qualities of a significant mining area: Emet Stream Basin (Turkey), Environmental Earth Sciences, 71(5), pp. 2185-2197.

Vosyliene, M.Z. \& Jankaite, A. (2006). Effect of heavy metal model mixture on rainbow trout biological parameters, Ekologija, 4, pp. 12-17.

Xu, Y.J., Liu, X.Z. \& Ma, A.J. (2004). Current research on toxicity effect and molecular mechanism of heavy metals on fish, Marine Science, 28 (10), pp. 67-70.

Yarar, M. \& Magnin, G. (1997). Important bird areas of Turkey, Natural Life Protection Association, İstanbul: 1-313. (in Turkish)

Yu, G.B., Liu, Y., Yua, S., Wuc, S.C., Leung A.O. W., Luo, X.S., Xua, B., Li, H.B. \& Wongc, M.H. (2011). Inconsistency and comprehensiveness of risk assessments for heavy metals in urban surface sediments, Chemosphere, 85, pp. 1080-1087. 